\title{
Zeolite/sintered metal fibers composites as effective structured catalysts
}

\author{
Igor Yuranov, Albert Renken, Lioubov Kiwi-Minsker* \\ Laboratory of Chemical Reaction Engineering, Swiss Federal Institute of Technology, LGRC-EPFL, CH-1015 Lausanne, Switzerland
}

Received 4 September 2004; received in revised form 3 November 2004; accepted 8 November 2004

Available online 15 December 2004

\begin{abstract}
The catalytic filters of sintered metal fibers (SMF) coated by thin MFI-type zeolite (silicalite-1, ZSM-5) films have been synthesized and tested in the reactor with structured catalytic bed. The catalysts show multifunctional behavior, combining catalysis with heat exchange, mixing, and particulates removal. The reactors based on the zeolite/SMF composite elements have a three-level structure: (i) a micro-scale due to oriented submicron zeolite crystals; (ii) a meso-scale due to homogeneous porosity of metal fiber filters; (iii) a macro-scale due to the design characteristics of the catalyst packing. The catalytic bed of the FeZSM-5/SMF Fecralloy was efficient and the one-step benzene hydroxylation to phenol with $\mathrm{N}_{2} \mathrm{O}$ at temperatures as low as $270{ }^{\circ} \mathrm{C}$ without loosing $\mathrm{N}_{2} \mathrm{O}$ via decomposition to nitrogen and oxygen (selectivity close to $100 \%$ ). The catalyst was effective in the $\mathrm{N}_{2} \mathrm{O}$ decomposition at temperatures $400-500{ }^{\circ} \mathrm{C}$.
\end{abstract}

(C) 2004 Elsevier B.V. All rights reserved.

Keywords: Structured catalysts; Multifunctional reactor; Zeolite coating; Sintered metal fibers

\section{Introduction}

During the last decades the needs are growing for new materials useful in multifunctional catalytic reactors capable of carrying out together with chemical reaction other functions like mixing, heat exchange, separation, etc. Membrane reactors and reactive distillation columns provide separation of reactants and products. The microchannel reactors ensure also the heat exchange, and the reactors with a periodic flow reversal allow the higher than adiabatic temperature to be attained [1]. Multifunctional reactors using catalytic filters ensure besides catalysis reactant mixing, heat exchange and particulates removal [2]. This study is focused on the structure of the filter body and catalytically active layer deposited on it. Sintered metal fibre (SMF) filters have uniform micron size filaments sintered into a homogeneous 3D structure and present porosities up to $80-90 \%$, large permeability and excellent filtrating properties. Fibres made of alloys (stainless steel, Inconel,

\footnotetext{
* Corresponding author. Tel.: +41 21693 3182; fax: +41 216933190 E-mail address: lioubov.kiwi-minsker@epfl.ch (L. Kiwi-Minsker).
}

Fecralloy) exhibit high mechanical strength, and chemical as well as thermal stability. High thermal conductivity of the metal fiber matrix provides a radial heat transfer about twofold higher compared to the randomly packed catalytic beds [3], leading to a nearly isothermal conditions. The fibrous matrix acts also as a static micromixer avoiding channeling. In Fecralloy fibers the aluminium diffuses at high temperatures from the bulk towards the surface where it is oxidized generating an $\alpha-\mathrm{Al}_{2} \mathrm{O}_{3}$ layer [4], which anchors the catalytically active phase. Available in the form of panels of different thickness, porosity and specific surface area (SSA), SMF filters are suitable for the design of catalytic beds of various shapes and structures with a porosity gradient or different active phase concentration [5].

Metal fibers (in the form of both knitted fabrics and nonwoven fiber media) have been used as supports for the preparation of catalytic filters [5-8] and zeolite membranes [9]. Zeolite layers have been also grown on metal plates [10-15], grids $[16,17]$ and metal reactor walls [18-20]. However, the fabrication of a uniform zeolite film with controlled thickness on the metal micro-fibers composing a 3D porous media is still a challenge. Despite the increasing interest on zeolitic coatings, only few applications have been reported 
[16,21]. ZSM-5 crystals grown on stainless-steel grids have been tested in the gas phase hydroxylation of benzene to phenol with $\mathrm{N}_{2} \mathrm{O}$ [17].

In this study we describe the FeZSM-5/SMF composites containing a zeolite film deposited on SMF filters, which present multi-scale structure characteristics useful for catalysis in the one-step hydroxylation of benzene to phenol with $\mathrm{N}_{2} \mathrm{O}$. This industrially important reaction was chosen as model reaction to test the developed composite materials for the operation of highly exothermic reactions. The overall reaction enthalpy of the hydroxylation of benzene to phenol at $400{ }^{\circ} \mathrm{C}$ is $259 \mathrm{~kJ} \mathrm{~mol}^{-1}$. The enthalpies of undesired further oxidations of phenol are even higher. Considering only the reaction of hydroxylation, a heat of $2750 \mathrm{~kJ}$ is released per every $\mathrm{kg}$ of phenol produced. Because of this, the temperature raises significantly in the reactor if the catalytic bed has poor heat transfer characteristics. On the contrary, the structured FeZSM-5/SMF composite with high thermal conductivity of metal fibers dissipates effectively the heat allowing isothermal operation of the exothermic reaction. This avoids hot-spot and runaway problems diminishing also zeolite deactivation and undesired $\mathrm{N}_{2} \mathrm{O}$ decomposition.

\section{Experimental}

\subsection{Materials}

Sintered metal fibers Bekipor ST 20AL3 (Bekaert Fiber Technology, Belgium) made of Inconel 601 (Ni 58-63\%; Cr 21-25\%; Al 1.4\%) in the form of a graded pore panel $\left(0.49 \mathrm{~mm}\right.$ thick, $81 \%$ porosity, $\left.750 \mathrm{~g} / \mathrm{m}^{2}\right)$ and Sintered metal fibers $40 \mu \mathrm{m}$ (Southwest Screens \& Filters SA, Belgium) made of Fecralloy (Cr 20\%; Al 4.75\%; Y 0.27\%; other elements $\sim 1-2 \%$; Fe balance) in the form of a uniform pore panel $\left(0.29 \mathrm{~mm}\right.$ thick, $71 \%$ porosity, $\left.675 \mathrm{~g} / \mathrm{m}^{2}\right)$ were used as supports for zeolite coating. Chemicals (Fluka, Aldrich, $>98 \%$ ) and gases (Carbagas, $>99.99 \%$ ) were used as received.

\subsection{Catalyst preparation}

In order to remove contaminations and to create an oxide layer on the metal surface, the SMF panels $(4 \mathrm{~cm} \times 6 \mathrm{~cm})$ were boiled two times in toluene for $0.5 \mathrm{~h}$, dried and calcined in air at $600{ }^{\circ} \mathrm{C}$. The supports were then treated in a $0.5 \%$ aqueous solution of poly(dimethylamine-co-epichlorohydrine) for $0.5 \mathrm{~h}$, rinsed in a $0.1 \mathrm{M}$ ammonia solution and air-dried. Colloidal seed crystals of silicalite-1 were prepared from a mixture containing tetrapropylammonium hydroxide, TPAOH, tetraethoxysilane, TEOS, water and ethanol in the ratio 9 TPAOH:25 TEOS: $480 \mathrm{H}_{2} \mathrm{O}: 100$ $\mathrm{C}_{2} \mathrm{H}_{5} \mathrm{OH}[10,22]$. The mixture was treated hydrothermally with reflux at $100{ }^{\circ} \mathrm{C}$ for $48 \mathrm{~h}$. The obtained silicalite- 1 sol was purified four times by centrifugation and re-dispersion in water. The final $\mathrm{pH} 10$ was adjusted by addition of aqueous ammonia. The polyelectrolyte modified SMF panels were immersed in the seed sol for $0.5 \mathrm{~h}$. After adsorption of the seeds, the supports were rinsed in a $0.1 \mathrm{M}$ $\mathrm{NH}_{3}$ solution with sonication (four times), dried and calcined in air at $550{ }^{\circ} \mathrm{C}$ for $4 \mathrm{~h}$. In order to form a zeolite film on the metal surface, the seeded filters were placed in a synthesis gel and treated hydrothermally in a $200 \mathrm{ml}$ autoclave at $175^{\circ} \mathrm{C}$ for $24 \mathrm{~h}$. The molar composition of the clear synthesis gel was 10 TPAOH:40 TEOS:20,000 $\mathrm{H}_{2} \mathrm{O}$. The treated samples were then rinsed in a $0.1 \mathrm{M} \mathrm{NH}_{3}$ solution, treated in an ultrasonic bath and air-dried. Fecontaining ZSM-5 layers active in benzene hydroxylation and $\mathrm{N}_{2} \mathrm{O}$ decomposition were grown from the same synthesis gel with addition of $\mathrm{NaAlO}_{2}$ (Riedel-de Haën) and $\mathrm{Fe}\left(\mathrm{NO}_{3}\right)_{3}$ aq (Fluka) (Si:Al:Fe = 50:1:0.017). In order to increase the zeolite film thickness, the hydrothermal treatment could be repeated. The obtained zeolite/SMF samples were calcined in air at $550{ }^{\circ} \mathrm{C}$ for $24 \mathrm{~h}$ to remove the organic template. The ZSM-5/SMF sample was then converted into the $\mathrm{H}$-form by ion-exchange with a $1 \mathrm{M}$ $\mathrm{NH}_{4} \mathrm{NO}_{3}$ aqueous solution $\left(24 \mathrm{~h}, 20^{\circ} \mathrm{C}\right)$ followed by calcination at $550{ }^{\circ} \mathrm{C}$ for $4 \mathrm{~h}$. The FeZSM-5/Fecralloy catalyst was activated by steaming $\left(\mathrm{H}_{2} \mathrm{O}\right.$ partial pressure of 0.3 bar, He flow) at $550{ }^{\circ} \mathrm{C}$ for $4 \mathrm{~h}$.

\subsection{Catalyst characterization}

The Si/Al ratio in the zeolites was determined by atomic absorption spectroscopy via a Shimadzu AA-6650 spectrometer after dissolving the $\mathrm{Si} / \mathrm{Al}$ coating in aqueous HF. The specific surface areas (SSA) were measured using $\mathrm{N}_{2}$ adsorption-desorption at $77 \mathrm{~K}$ via a Sorptomatic 1990 instrument (Carlo Erba) after catalyst pre-treatment in vacuum at $523 \mathrm{~K}$ for $2 \mathrm{~h}$ and calculated employing the BET method. X-ray diffraction (XRD) patterns of catalysts were obtained on a Siemens D500 diffractometer with $\mathrm{Cu} \mathrm{K} \alpha$ monochromatic radiation $(\lambda=1.5406 \AA)$.

\subsection{Catalyst testing}

The activated FeZSM-5/SMF Fecralloy catalyst was tested in the $\mathrm{N}_{2} \mathrm{O}$ decomposition and benzene hydroxylation using a vertical stainless-steel tubular reactor [23] (i.d. $20 \mathrm{~mm}$ ) at atmospheric pressure. The FeZSM-5/SMF Fecralloy panels were cut into $20 \mathrm{~mm}$ disks, and a stack of 80 disks (height $\sim 25 \mathrm{~mm}, \mathrm{~m}_{\mathrm{FeZSM}-5}=1.0 \mathrm{~g}$ ) was placed coaxially in the middle part of the reactor. Before testing, the catalyst was always pretreated in $\mathrm{He}$ at $500{ }^{\circ} \mathrm{C}$ for $2 \mathrm{~h}$. The gas mixture of 2 vol. \% of $\mathrm{N}_{2} \mathrm{O}, 98 \mathrm{vol} . \%$ of $\mathrm{He}$ was used for the $\mathrm{N}_{2} \mathrm{O}$ decomposition. The mixture of 1 vol. $\%$ of $\mathrm{C}_{6} \mathrm{H}_{6}, 5$ vol.\% of $\mathrm{N}_{2} \mathrm{O}, 94 \mathrm{vol} . \%$ of He was used for the benzene hydroxylation. Benzene was fed into the reactor by passing He through a thermostated $\left(20^{\circ} \mathrm{C}\right)$ bubble column. The gas flows were controlled by mass flow controllers. The total gas flow was $60 \mathrm{ml}$ (STP)/min through the testing. The reaction tem- 
perature was monitored by a thermocouple placed upstream on the top of the catalytic bed. The reaction mixtures were analyzed by on-line GC (Perkin-Elmer Autosystem XL). The organic components were separated in a SPB-5 capillary column and detected by FID. The light gases $\left(\mathrm{N}_{2}, \mathrm{O}_{2}, \mathrm{~N}_{2} \mathrm{O}, \mathrm{CO}\right.$ and $\left.\mathrm{CO}_{2}\right)$ were separated in a Carboxen1010 capillary column and detected by TCD.

During $\mathrm{N}_{2} \mathrm{O}$ decomposition, the reaction temperature was increased (heating rate of $5 \% \mathrm{~min}$ ) stepwise by $25^{\circ}$ from 300 to $550{ }^{\circ} \mathrm{C}$. The $\mathrm{N}_{2} \mathrm{O}$ conversion was measured at each temperature after the transient period of ca. $60 \mathrm{~min}$. The conversion of benzene was calculated from the difference between its reactor inlet and outlet concentrations. The selectivity towards phenol was defined as the molar ratio of the phenol obtained to the benzene converted.

To investigate the influence of $\mathrm{H}_{2} \mathrm{O}$ vapor on the catalyst stability, water $(5 \mu \mathrm{l})$ was injected by a syringe in the heated $\left(\sim 100{ }^{\circ} \mathrm{C}\right)$ gas line connected to the reactor inlet.

\section{Results and discussion}

\subsection{Catalysts}

The zeolite/SMF composite synthesis involves three steps [12]. The metal substrate surface was first modified by a polyelectrolyte to obtain a suitable surface charge. In the second step, colloidal zeolite nanocrystals (seeds, 80$100 \mathrm{~nm})[10,22]$ are adsorbed onto the substrate surface. The crystals were firmly attached to the surface, since they are not removed by ultrasonication in a $0.1 \mathrm{M} \mathrm{NH}_{3}$ solution. Finally, the adsorbed seeds grow into a homogeneous film of zeolite crystals during hydrothermal synthesis. Diluted synthesis solutions $(0.002-0.1 \mathrm{M})$ allow suppressing the homogeneous zeolite nucleation in the bulk rendering the heterogeneous growth of the zeolite film. The zeolite loading is controlled by varying the synthesis time or by repetition of the hydrothermal treatment.

As seen in SEM images (Figs. 1 and 2), the deposited zeolite films were uniform on the elementary filaments of the
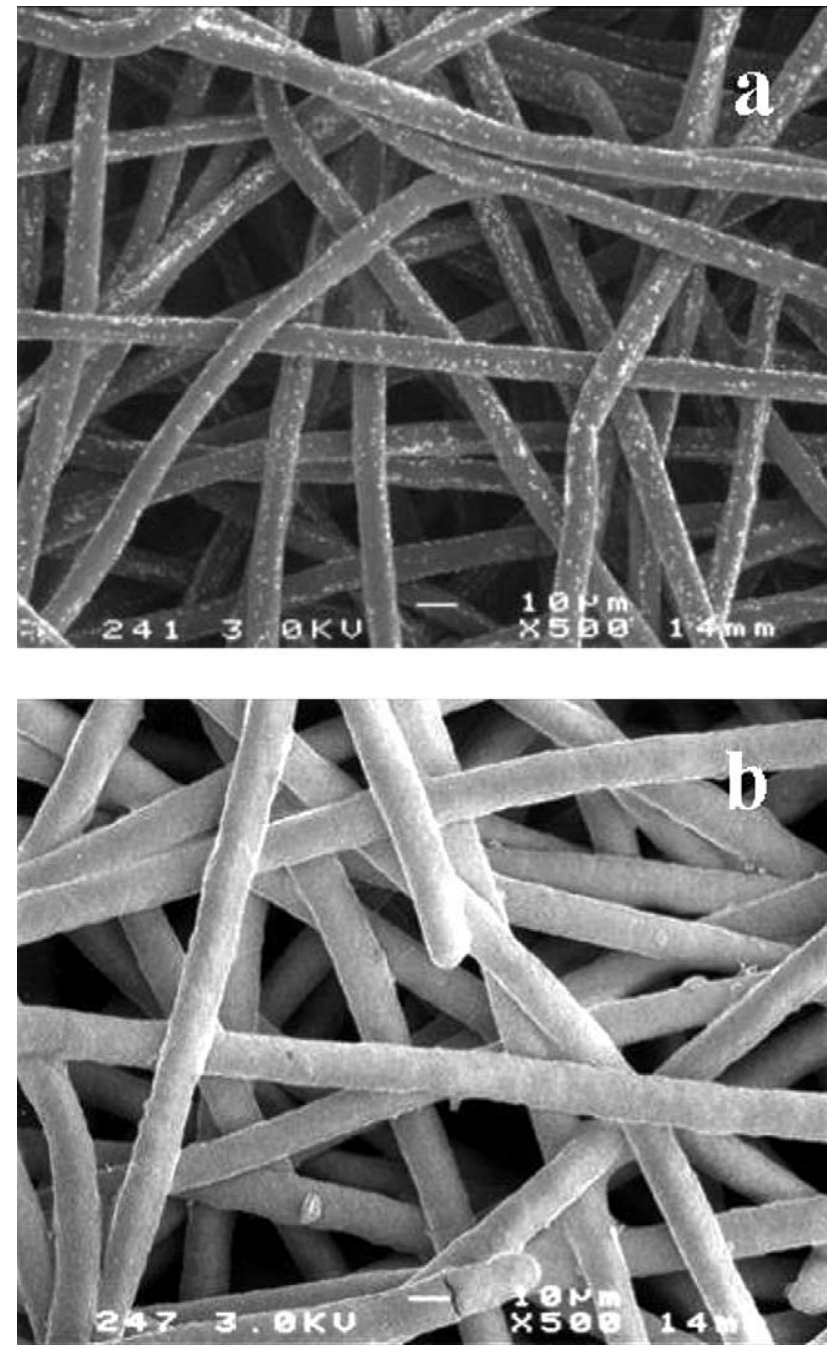

Fig. 1. Sintered Metal (Inconel 601) Fibers: (a) calcined; (b) coated by silicalite-1 (loading $\sim 15$ wt.\%).

SMF filters. No cracks were observed after calcination at $550{ }^{\circ} \mathrm{C}$. The coating consists of highly intergrown crystals about $1 \mu \mathrm{m}$ in size with prismatic MFI morphology. The XRD patterns confirmed the existence of the crystalline MFI

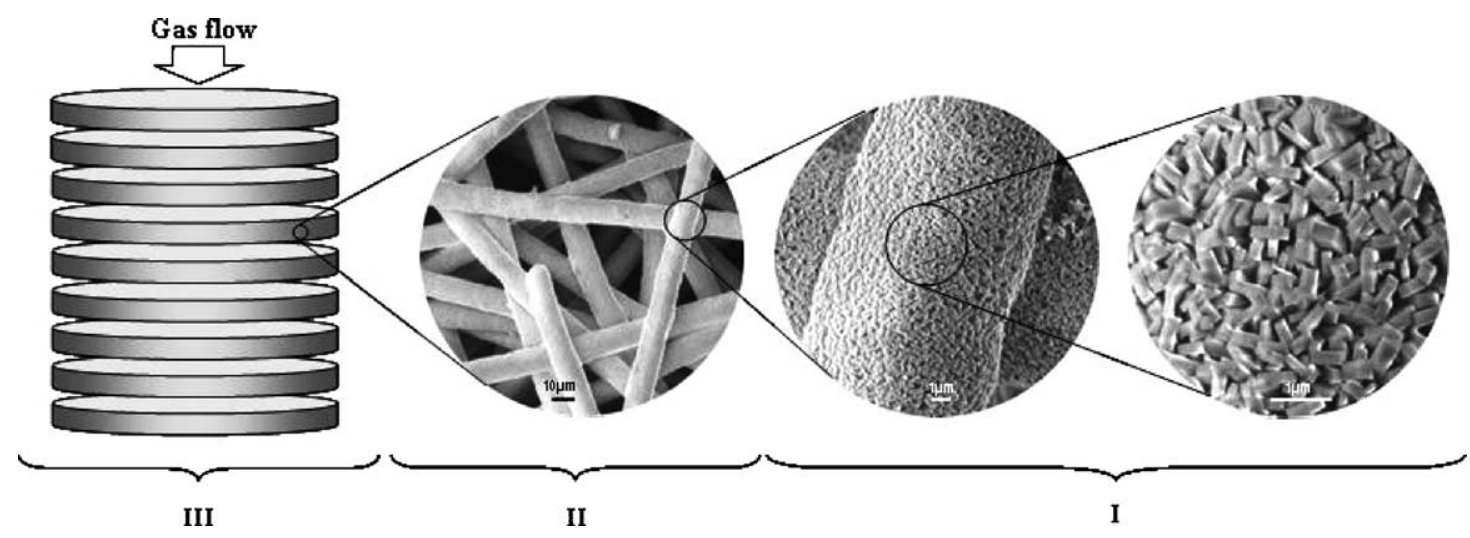

Fig. 2. Three-level structure of the zeolite/SMF structured catalytic bed: (I) a micro-structure of the zeolite film of oriented submicron crystals; (II) mesostructure of the porous SMF layer; (III) macro-structure of the layered catalytic bed. 
phase. The specific surface area (SSA) measured for microporous zeolite coatings was $300-320 \mathrm{~m}^{2} / \mathrm{g}$. A minor mesopores fraction with $4-5 \mathrm{~nm}$ was also detected. The zeolite crystals are oriented with the $a$-axis perpendicular to the substrate surface. Such an orientation is particularly beneficial for catalytic applications, since a maximum crystal surface is available for reactants. The zeolite coating thickness is varied from hundreds nanometers and upwards depending on the synthesis conditions and the diameter of metal filaments. For example, a film of $1.3-1.4 \mu \mathrm{m}$ thickness was obtained on $6 \mu \mathrm{m}$ metal fibers after $24 \mathrm{~h}$ of crystallization. The Si/Al ratio in the ZSM-5 coatings $(\sim 100)$ was always higher than in the initial synthesis solution $(\sim 50)$ indicating the hindering of isomorphous substitution of $\mathrm{Si}^{4+}$ by $\mathrm{Al}^{3+}$ in MFI lattice. This is probably due to a concentration gradient in the synthesis solution under static conditions. The presence of iron in the SMF supports did not allow the analysis of Fe content in the synthesized FeZSM-5 coating. Nevertheless, we believe that the Fe concentration in the zeolite does not exceed a few hundred ppm.

The catalyst packing of zeolite/SMF elements (disks) presents a three-level structure (Fig. 2): (1) a micro-structure of zeolite film with submicron zeolite crystals; (2) a mesostructure of a porous 3D media of sintered metal fibres; (3) a macro-structure of the layered catalytic bed formed from the composite elements. Each level is adopted for a specific function (filtration, mixing, heat transfer, chemical reaction, etc.) thus forming a multifunctional catalyst. Due to the uniform thin zeolite film, the zeolite/SMF composite elements retain the structure and hydrodynamic properties of the original SMF filters. About 80 disks $(d=20 \mathrm{~mm})$ of the FeZSM-5/SMF Fecralloy (zeolite loading-6.3 wt.\%) were stacked to create a structured catalytic bed. The pressure drop of 5-10 $\mathrm{mm} \mathrm{H}_{2} \mathrm{O}$ column was detected at the gas flow rate of $60-100 \mathrm{ml} / \mathrm{min}$. Highly oriented ZSM-5 crystals do not present any internal diffusion limitations for gaseous reactants due to submicron dimensions. The high thermal conductivity of the metal fibers dissipates the heat in the catalytic bed avoiding hot-spots formation. Therefore, isothermal conditions are attained allowing a better control of the reaction selectivity. In general, the composite elements staging the structured catalytic bed could have different characteristics (support structure, active phase composition, etc.) providing additional parameters for a design of multifunctional reactors.

\section{2. $\mathrm{N}_{2} \mathrm{O}$ decomposition}

The decomposition of $\mathrm{N}_{2} \mathrm{O}$ into $\mathrm{N}_{2}$ and $\mathrm{O}_{2}$ is known to be catalyzed by $\mathrm{Fe}$-containing ZSM-5 at temperatures higher than $300-400{ }^{\circ} \mathrm{C}$. This decomposition being an important reaction for the pollution control becomes undesired if it takes place in parallel to the benzene hydroxylation to phenol. Therefore, the synthesized structured FeZSM-5/ $\mathrm{SMF}_{\text {Fecralloy }}$ (zeolite loading of $\sim 6.3 \mathrm{wt} . \%$ ) catalyst was

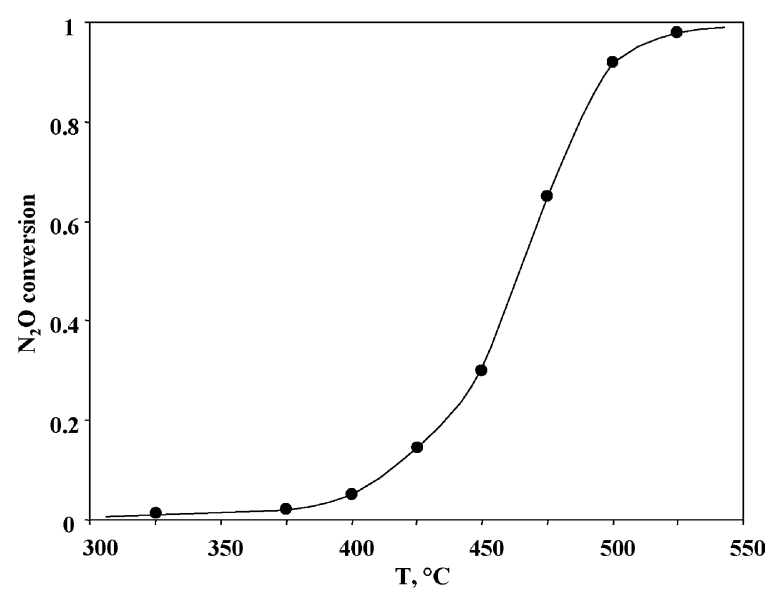

Fig. 3. Conversion as a function of temperature during the $\mathrm{N}_{2} \mathrm{O}$ decomposition (reaction mixture: 2 vol. $\%$ of $\mathrm{N}_{2} \mathrm{O}, 98$ vol.\% of $\mathrm{He}$ ) over the FeZSM-5/SMF Fecralloy $\left(\mathrm{m}_{\mathrm{FeZSM}-5}=1.0 \mathrm{~g}\right)$ structured catalytic bed.

tested in $\mathrm{N}_{2} \mathrm{O}$ decomposition. The results obtained under dry conditions are presented in Fig. 3. Before testing, the catalyst was always pretreated in $\mathrm{He}$ or in air at $500^{\circ} \mathrm{C}$ for $2 \mathrm{~h}$. As it is seen, the reaction started at $>300{ }^{\circ} \mathrm{C}$, and a conversion close to $100 \%$ was attained at $\sim 520{ }^{\circ} \mathrm{C}$. The catalyst was stable without any deactivation for $20 \mathrm{~h}$ on stream within the temperature region studied.

A decrease of the FeZSM-5 catalyst activity in $\mathrm{N}_{2} \mathrm{O}$ decomposition at $500{ }^{\circ} \mathrm{C}$ in the presence of water vapor has been recently reported $[24,25]$. Active sites hydroxylation/ deactivation and water condensation in the zeolite micropores were claimed to be the reasons for the observed behavior $[26,27]$. In the present study the reaction dynamics was examined after water vapor injection $(5 \mu \mathrm{l})$ at $450{ }^{\circ} \mathrm{C}$ in order to investigate the stability of the thin zeolite coating under these conditions (Fig. 4). The decrease of $\mathrm{N}_{2} \mathrm{O}$ conversion was $\sim 75 \%$ with respect to that attained with a dry gas feed. However, the loss of the FeZSM-5/SMF Fecralloy catalyst activity was observed to be reversible. About $3 \mathrm{~h}$

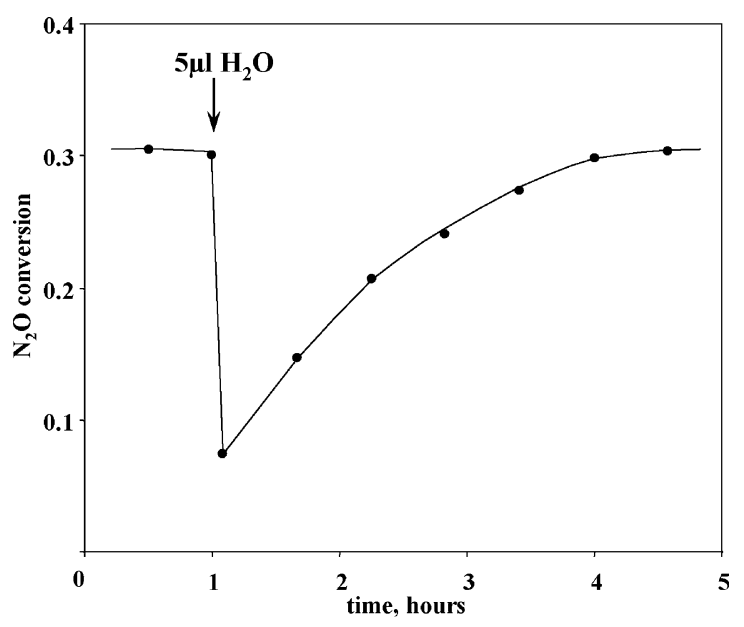

Fig. 4. The effect of water on the $\mathrm{N}_{2} \mathrm{O}$ conversion at $450{ }^{\circ} \mathrm{C}$ over the FeZSM-5/SMF $F_{\text {Fecralloy }}$ structured catalytic bed. 
using dry stream of reactants were needed to return back to the initial steady-state. This result indicates that the composites are stable at high temperature and the presence of water vapor does not deteriorate the deposited zeolite films.

\subsection{One-step benzene hydroxylation to phenol with $\mathrm{N}_{2} \mathrm{O}$}

The catalytic activity of ZSM-5 in the benzene hydroxylation to phenol with nitrous oxide is due to iron present in the zeolite [28-30]. Fe(II) species of low nuclearity stabilized in extraframework positions in the zeolite micropores are believed to be responsible for the activity $[27,31,32] . \mathrm{Fe}_{2} \mathrm{O}_{3}$ nanoparticles catalyze the total oxidation of benzene. It was found that they are not formed during activation of low-concentrated $(<500 \mathrm{ppm})$ isomorphously substituted FeZSM-5 zeolites [33]. Therefore, a small quantity of $\mathrm{Fe}^{3+}$-ions (300 ppm on a $\mathrm{SiO}_{2}$ basis) was added to the initial zeolite synthesis gel in order to introduce Fe ions in the zeolite extraframework. The resulting FeZSM$5 / \mathrm{SMF}_{\text {Fecralloy }}$ (zeolite loading of $\sim 6.3 \mathrm{wt} . \%$ ) composite was calcined and activated by steaming. The beneficial effect of steaming on the activity of ZSM-5 catalysts is well known $[30,34,35]$. Steam treatment leads to a significant dealumination of the zeolite lattice and the expulsion of isomorphously substituted $\mathrm{Fe}^{3+}$-ions. This process is accompanied by partial $\mathrm{Fe}(\mathrm{III})$ auto-reduction and the formation of extraframework $\mathrm{Fe}(\mathrm{II})$ active species $[32,36]$.

The performance of the FeZSM-5/SMF Fecralloy catalyst in hydroxylation of benzene was observed to be highly selective $(>98 \%)$ towards phenol formation at $270{ }^{\circ} \mathrm{C}$ (Fig. 5). The phenol production at this temperature was estimated to be $\sim 0.08 \mathrm{mmol} \mathrm{h}^{-1} \mathrm{~g}_{\text {zeolite }}{ }^{-1}$. As was mentioned above (see Section 3.2) the reaction of $\mathrm{N}_{2} \mathrm{O}$ decomposition starts at temperatures $>300{ }^{\circ} \mathrm{C}$. Thus, carrying out the reaction at $270{ }^{\circ} \mathrm{C}$, one can avoid the

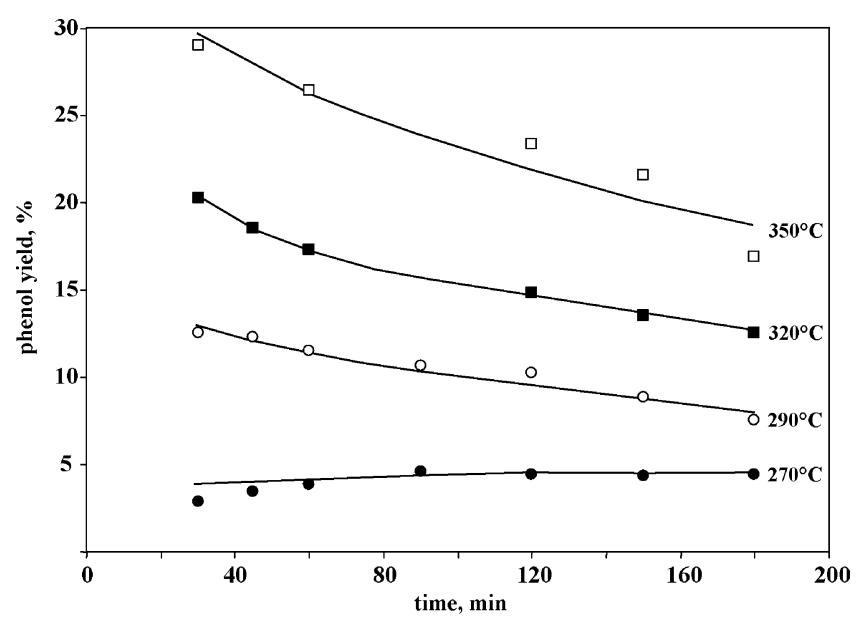

Fig. 5. Hydroxylation of benzene to phenol with $\mathrm{N}_{2} \mathrm{O}$ (reaction mixture: 1 vol. \% of $\mathrm{C}_{6} \mathrm{H}_{6}, 5$ vol. $\%$ of $\mathrm{N}_{2} \mathrm{O}, 94 \mathrm{vol} . \%$ of $\mathrm{He}$; total gas flow $=60 \mathrm{ml} /$ $\mathrm{min})$ over the FeZSM-5/SMF Fecralloy $\left(\mathrm{m}_{\mathrm{FeZSM}-5}=1.0 \mathrm{~g}\right)$ structured catalytic bed.
$\mathrm{N}_{2} \mathrm{O}$ decomposition and the occurrence of molecular oxygen, which leads to catalyst deactivation due to coke formation in the zeolite micropores [35,37-42]. High selectivity of $\mathrm{N}_{2} \mathrm{O}$ conversion to phenol improves the process feasibility due to a high price of nitrous oxide. At higher temperatures, the catalyst deactivation is always observed. However, the reaction selectivity towards phenol remains in the range of $95-98 \%$ at temperatures up to $350{ }^{\circ} \mathrm{C}$. The catalyst could be reactivated by calcination in air or in $\mathrm{He}$ at $500{ }^{\circ} \mathrm{C}$ during $2 \mathrm{~h}$.

\section{Conclusions}

1. Novel catalytic filters based on the sintered metal fibers (SMF) coated by MFI-zeolite have been developed for the reactors with structured catalytic beds. Such reactors are multifunctional and capable of carrying out, besides catalysis, reactant mixing, heat exchange and particulates removal. The thickness of the zeolite layer could be controlled by the synthesis conditions. The zeolite films contained highly oriented submicron crystals.

2. Zeolite/SMF composites have the three-level structure of (i) the submicron zeolite crystals, (ii) the homogeneous porous media with high thermal conductivity due to the metal fibers, and (iii) the macro-structure of the catalyst packing.

3. The catalytic bed of the Fe-containing ZSM-5/ $\mathrm{SMF}_{\text {Fecralloy }}$ was found efficient in stoichiometric decomposition of $\mathrm{N}_{2} \mathrm{O}$ to $\mathrm{N}_{2}$ and $\mathrm{O}_{2}$ at $300-500{ }^{\circ} \mathrm{C}$ under dry conditions. However, the catalyst activity is reversibly inhibited by water vapor.

4. The catalytic bed was used in the one-step benzene-tophenol transformation with $\mathrm{N}_{2} \mathrm{O}$. Phenol was observed to be formed with the selectivity close to $100 \%$ at temperatures as low as $270{ }^{\circ} \mathrm{C}$. Carrying out the reaction at such low temperatures saves nitrous oxide, since the reaction of $\mathrm{N}_{2} \mathrm{O}$ decomposition starts $>300{ }^{\circ} \mathrm{C}$. Furthermore, no catalyst deactivation was detected at $270{ }^{\circ} \mathrm{C}$.

\section{Acknowledgments}

The authors thank the Swiss National Science Foundation for the financial support.

\section{References}

[1] G. Saracco, V. Specchia, in: A. Cybulski, J.A. Moulijn (Eds.), Structured Catalysts and Reactors, Marcel Dekker, New York, 1998 p. 417.

[2] G. Saracco, V. Specchia, Chem. Eng. Sci. 55 (2000) 897.

[3] D.R. Cahela, B.J. Tatarchuk, Catal. Today 69 (2001) 33.

[4] C. Badini, F. Laurella, Surface and Coatings Technology 135 (2001) 291.

[5] I. Yuranov, L. Kiwi-Minsker, A. Renken, Appl. Catal. B: Environ. 43 (2003) 217 
[6] C.J. Marrion, D.R. Cahela, S. Ahn, B.J. Tatarchuk, J. Power Sources 47 (1994) 297.

[7] I. Cerri, M. Pavese, G. Saracco, V. Specchia, Catal. Today 83 (2003) 19.

[8] Y. Wang, Y. Tang, X. Wang, W. Shan, C. Ke, Z. Gao, J. Hu, W. Yang, J. Mater. Sci. Lett. 20 (2001) 2091.

[9] S.M. Holmes, C. Markert, R.J. Plaisted, J.O. Forrest, J.R. Agger, M.W. Anderson, C.S. Cundy, J. Dwyer, Chem. Mater. 11 (1999) 3329.

[10] S. Mintova, V. Valtchev, V. Engström, B.J. Schoeman, J. Sterte, Micropor. Mater. 11 (1997) 149.

[11] S. Mintova, V. Valtchev, L. Konstantinov, Zeolites 17 (1996) 462.

[12] J. Sterte, J. Hedlund, D. Creaser, O. Ohrman, W. Zheng, M. Lassinantti, Q. Li, F. Jareman, Catal. Today 69 (2001) 323.

[13] T. Cetin, M. Tatlier, A. Erdem-Senatalar, U. Demirler, M. Urgen, Micropor. Mesopor. Mater. 47 (2001) 1.

[14] Z. Wang, J. Hedlund, J. Sterte, Micropor. Mesopor. Mater. 52 (2002) 191.

[15] Z. Wang, Y. Yan, Chem. Mater. 13 (2001) 1101.

[16] H.P.A. Calis, A.W. Gerritsen, C.M. van den Bleek, C.M. Legein, J.C. Jansen, H. van Bekkum, Can. J. Chem. Eng. 73 (1995) 120128.

[17] B. Louis, P. Reuse, L. Kiwi-Minsker, A. Renken, Appl. Catal. A 210 (2001) 103

[18] Z. Shan, W.E.J. van Kooten, O.L. Oudshoorm, J.C. Jansen, H. van Bekkum, C.M. van den Bleek, H.P.A. Calis, Micropor. Mesopor. Mater. 34 (2000) 81.

[19] Y.S.S. Wan, J.L.H. Chau, A. Gavriilidis, K.L. Yeung, Micropor. Mesopor. Mater. 42 (2001) 157.

[20] E.V. Rebrov, G.B.F. Sejger, H.P.A. Calis, M.H.J.M. de Croon, C.M. van den Bleek, J.C. Schouten, Appl. Catal. A: Gen. 206 (2001) 125.

[21] J.C. Jansen, J.H. Koegler, H. van Bekkum, H.P.A. Calis, C.M. van den Bleek, F. Kapteijn, J.A. Moulijn, E.R. Geus, N. van der Puil, Micropor. Mesopor. Mater. 21 (1998) 213.

[22] A.E. Persson, B.J. Schoeman, J. Sterte, J.-E. Otterstedt, Zeolites 14 (1994) 557.
[23] I. Yuranov, L. Kiwi-Minsker, A. Renken, Appl. Catal. B 43 (2003) 217.

[24] E.M. El-Malki, R.A. van Santen, W.M.H. Sachtler, Micropor. Mesopor. Mater. 35-36 (2000) 235.

[25] D.A. Bulushev, L. Kiwi-Minsker, A. Renken, J. Catal. 222 (2004) 389.

[26] J. Péres-Ramíres, F. Kapteijn, G. Mul, J.A. Moulijn, Appl. Catal. B: Environ. 35 (2002) 227.

[27] L. Kiwi-Minsker, D.A. Bulushev, A. Renken, J. Catal. 219 (2003) 273.

[28] P.P. Notté, Top. Catal. 13 (2000) 387.

[29] K.A. Dubkov, N.S. Ovanesyan, A.A. Shteinman, E.V. Starokon, G.I. Panov, J. Catal. 207 (2002) 341.

[30] J. Jia, K.S. Pillai, W.M.H. Sachtler, J. Catal. 221 (2004) 119.

[31] G.I. Panov, A.K. Uriarte, M.A. Rodkin, V.I. Sobolev, Catal. Today 41 (1998) 365.

[32] E.J.M. Hensen, Q. Zhu, M.M.R.M. Hendrix, A.R. Overweg, P.J. Kooyman, M.V. Sychev, R.A. van Santen, J. Catal. 221 (2004) 560.

[33] I. Yuranov, D.A. Bulushev, A. Renken, L. Kiwi-Minsker, J. Catal. 227 (2004) 138

[34] Q. Zhu, R.M. van Teeffelen, R.A. van Santen, E.J.M. Hensen, J. Catal. 221 (2004) 575.

[35] P. Kubánek, B. Wichterlová, Z. Sobalík, J. Catal. 211 (2002) 109.

[36] J. Pérez-Ramírez, G. Mul, F. Kapteijn, J.A. Moulijn, A.R. Overweg, A. Doménech, A. Ribera, I.W.C.E. Arends, J. Catal. 207 (2002) 113.

[37] G.I. Panov, A.S. Kharitonov, V.I. Sobolev, Appl. Catal. A: Gen. 98 (1993) 1

[38] M. Hafele, A. Reitzmann, D. Roppelt, G. Emig, Appl. Catal. A: Gen. 136 (1997) 153.

[39] A. Ribera, I.W.C.E. Arends, S. de Vries, J. Péres-Ramíres, R.A. Sheldon, J. Catal. 195 (2000) 287.

[40] D.P. Ivanov, V.I. Sobolev, G.I. Panov, Appl. Catal. A: Gen. 241 (2003) 113.

[41] E.J.M. Hensen, Q. Zhu, R.A. van Santen, J. Catal. 220 (2003) 260.

[42] S. Perathoner, F. Pino, G. Centi, G. Giordano, A. Kattovic, J.B. Nagy, Top. Catal. 23 (2003) 125. 